\title{
Intestinal microbiome: role in functional gastrointestinal disorders and contemporary diagnostic options
}

\author{
Mikrobiom jelitowy - współczesne możliwości diagnostyczne i rola \\ w zaburzeniach czynnościowych przewodu pokarmowego
}

\begin{abstract}
The most common problems that paediatricians and paediatric gastroenterologists encounter in their practice include functional gastrointestinal disorders. These are a group of chronic and/or recurrent conditions caused by any combination of gastrointestinal motility disturbances and visceral hypersensitivity with abnormal processing of stimuli in the central nervous system which manifest with abdominal pain, nausea and vomiting or disorders of defecation, among other problems. The symptoms cannot be assigned to any other clinical condition despite proper diagnostic investigation. The aetiology of functional gastrointestinal disorders is multifactorial. Recently, the role of the intestinal microbiota as an important environmental factor in the pathogenesis of such disorders has been investigated. In this article, the latest data regarding the composition of the microbiome (a collection of microbiota genes) of the human gastrointestinal tract are discussed and the methods used to determine it in detail are described. Currently, molecular biology techniques have the highest diagnostic value, which are based on genetic material sequencing. Due to their extraordinary efficacy, they are superseding classic microbiological tests. In addition, the publication presents factors which affect the composition of the gastrointestinal microbiome. These include, for example, mode of birth, method of infant feeding, diet at later stages of life, place of residence, physical activity and antibiotics intake. The research to date demonstrated that dysbiosis is one of the factors contributing to the pathogenesis of many diseases, including irritable bowel syndrome. Attempts at modifying the composition of the microbiome by, for example, the administration of probiotics, should therefore have a distinctly positive effect on patients with functional gastrointestinal disorders.
\end{abstract}

Keywords: microbiome, dysbiosis, abdominal pain, irritable bowel syndrome (IBS)

Streszczenie Do podstawowych problemów, z jakimi najczęściej stykają się w swojej praktyce pediatrzy i gastroenterolodzy dziecięcy, należą zaburzenia czynnościowe przewodu pokarmowego. Jest to grupa przewlekłych i/lub nawracających schorzeń wywołanych dowolną kombinacją zaburzeń motoryki i nadwrażliwości trzewnej z nieprawidłowym przetwarzaniem bodźców w ośrodkowym układzie nerwowym, objawiająca się między innymi bólami brzucha, nudnościami i wymiotami bądź zaburzeniami defekacji. Wymienionych symptomów nie można przypisać innemu stanowi klinicznemu, pomimo przeprowadzenia odpowiedniej diagnostyki. Etiologia czynnościowych zaburzeń przewodu pokarmowego jest wieloczynnikowa. W ostatnim czasie bada się rolę patogenetyczną mikrobioty jelitowej jako ważnego czynnika środowiskowego. W artykule omówiono najnowsze dane dotyczące składu mikrobiomu (zespołu genów mikrobioty) przewodu pokarmowego człowieka oraz scharakteryzowano metody wykorzystywane w celu jego szczegółowego określenia. Obecnie największą wartość diagnostyczną mają techniki biologii molekularnej, oparte na sekwencjonowaniu materiału genetycznego, które ze względu na wyjątkową skuteczność wypierają klasyczne badania mikrobiologiczne. Ponadto w publikacji przedstawiono czynniki odgrywające rolę w kształtowaniu składu mikrobiomu przewodu pokarmowego, do których zaliczają się między innymi droga porodu, sposób karmienia w okresie niemowlęcym, dieta w dalszych latach życia, miejsce zamieszkania, aktywność fizyczna czy przyjmowanie antybiotyków. Dotychczasowe badania wykazały, że dysbioza stanowi jeden z czynników patogenetycznych wielu chorób, w tym zespołu jelita drażliwego. Próby modyfikacji składu mikrobiomu, m.in. przez przyjmowanie probiotyków, powinny się więc wiązać z konkretną pomocą dla pacjentów z czynnościowymi zaburzeniami przewodu pokarmowego.

Słowa kluczowe: mikrobiom, dysbioza, bóle brzucha, zespół jelita drażliwego (IBS) 


\section{INTRODUCTION}

$\mathrm{F}$ unctional gastrointestinal disorders (FGIDs) are a group of chronic and/or recurrent conditions caused by any combination of motility disturbances and visceral hypersensitivity with abnormal processing of stimuli in the central nervous system. It is believed that at the peripheral (intestinal) level, the primary factor for visceral hyperactivity and hypersensitivity is abnormal function of the mucosa and gut-associated lymphoid tissue (GALT). Potential aetiological factors for functional gastrointestinal disorders include gastrointestinal infections, various endothelial irritants (including dietary ones such as allergy or food intolerance; medicines; environmental pollutants), changes to the intestinal microbiota and genetic factors. Activation of the intestinal immune system leads to local mucosal inflammation, release of various neurotransmitters and clinical manifestation with symptoms such as abdominal pain/discomfort, nausea/vomiting and defecation disturbances. Differential diagnostic investigation does not reveal any structural, inflammatory or metabolic abnormalities and any cancer lesions. Currently, among the potential aetiological factors for functional gastrointestinal tract disorders, gastrointestinal dysbiosis is of particular interest, which is a qualitative and quantitative imbalance of the intestinal microbiota ${ }^{(1)}$.

\section{MICROBIOTA AND MICROBIOME}

Microbiota is described as a group of microorganisms (bacteria, fungi, viruses and archaea, i.e. unicellular organisms) that colonise a certain environment. These organisms are not randomly scattered, but located in specific body compartments. The highest numbers of them are found in the gastrointestinal tract, particularly in the large intestine. It is estimated that the number of cells in the intestinal microbiota is comparable to that of all human cells and that it weighs approximately $1.5-2 \mathrm{~kg}^{(2)}$. The most common intestinal microorganisms come from the groups Firmicutes (e.g. Clostridium, Ruminococcus, Lactobacillus, Enterococcus, Streptococcus genera), Bacteroidetes (e.g. Bacteroides and Prevotella), Acinobacteria (e.g. Bifidobacterium) and Proteobacteria (e.g. Escherichia coli) (Tab. 1).

The term "microbiome," proposed by Joshua Lederberg in 2001, is used to refer to the genome of the microbiota encoded in DNA or RNA. As a result of advances in medical knowledge, the current diagnostic microbiology practice is no longer based exclusively on culture testing and serological methods, which allow one to identify only a minor proportion of bacterial species.

Currently, various molecular biology methods are used to investigate the microbiome, which are being constantly improved and are becoming increasingly available in clinical practice. They are primarily based on

\begin{tabular}{|l|l|}
\hline $\begin{array}{c}\text { Part } \\
\text { of gastrointestinal } \\
\text { tract }\end{array}$ & \multicolumn{1}{c|}{ Microbial genera } \\
\hline Oral cavity & $\begin{array}{l}\text { Streptococcus, Peptococcus, Staphylococcus, } \\
\text { Bifidobacterium, Lactobacillus, Fusobacterium }\end{array}$ \\
\hline Oesophagus & None \\
\hline Stomach & $\begin{array}{l}\text { Lactobacillus, Streptococcus, Enterobacteriaceae family, } \\
\text { Helicobacter, Candida yeasts }\end{array}$ \\
\hline Small intestine & $\begin{array}{l}\text { Lactobacillus, Streptococcus, Bifidobacterium, } \\
\text { Bacteroides, Clostridium, Enterococcus, Veillonella, } \\
\text { Enterobacteriaceae family }\end{array}$ \\
\hline Large intestine & $\begin{array}{l}\text { Bacteroides, Bifidobacterium, Eubacterium, } \\
\text { Fusobacterium, Ruminococcus, Lactobacillus, } \\
\text { Escherichia, Enterococcus, Bacillus, Clostridium, } \\
\text { Streptococcus, Peptostreptococcus, Candida yeasts }\end{array}$ \\
\hline
\end{tabular}

Tab. 1. Microbiome of different parts of the gastrointestinal tract ${ }^{(3)}$

the comparison of sequenced $16 \mathrm{~S}$ ribosomal RNA genes with gene sequences collected in databases. Since 1977, when Sanger et al. and Maxam and Gilbert introduced gene sequencing techniques, they have been constantly developed at a rapid pace ${ }^{(4)}$. Thanks to one of them, the shotgun method, in 1996 the genome sequence for the bacteria $H$. pylori was first published $\left(1.8 \times 10^{6}\right.$ base pairs $)^{(5)}$ and in 2001 the whole human genome was presented $\left(2.91 \times 10^{9} \text { base pairs }\right)^{(6)}$. Currently, the most advanced techniques include second-/next-generation sequencing (NGS) and third-generation sequencing $(\text { Tab. 2) })^{(7)}$.

The former employs high-throughput sequencers, which are able to sequence as many as a million DNA fragments at the same time. NGS methods make it possible to sequence complete bacterial genomes (whole-genome sequencing, WGS) and a large number of randomly fragmented DNA segments which are subsequently assembled by a computer (metasequencing, metabarcoding, shotgun sequencing). The whole process is performed in three stages: DNA isolation and library creation, matrix amplification and massive parallel sequencing.

Third-generation methods make it possible to read the sequence directly from a single DNA molecule (singlemolecule sequencing, SMS) without the need for amplification $^{(8)}$. The analysis of a sequence of genetic material collected directly from its environment is called metagenomics. Samples for intestinal microbiome studies may be a patient's stool or gastrointestinal mucosa fragments. Other important concepts related to microbiome investigation include metagenome (the entire DNA and RNA of cultivated and non-cultivated human microorganisms), metatranscriptome (the entire mitochondrial RNA), metaproteome (the total of synthesised bacterial proteins) and metabolome (the total of metabolism products) ${ }^{(8)}$.

\section{GASTROINTESTINAL MICROBIOTA}

The composition of the gastrointestinal microbiota depends on many factors and is subject to constant 


\begin{tabular}{|l|l|l|}
\hline \multirow{4}{*}{ First generation } & Sanger sequencing (chain termination method) & $\begin{array}{l}\text { DNA labelled with a fluorescent dye and subjected to polyacrylamide gel electrophoresis; } \\
\text { sequence determination based on the dye being excited with laser light }\end{array}$ \\
\cline { 2 - 3 } & Maxam-Gilbert sequencing & DNA labelled with a radioactive isotope of phosphorus; chemical degradation of DNA chain \\
\hline \multirow{4}{*}{$\begin{array}{l}\text { Second } \\
\text { generation } \\
\text { (NGS methods) }\end{array}$} & Pyrosequencing (454 Life Sciences) & $\begin{array}{l}\text { Real-time DNA synthesis recorded by measuring the amount of PPi released upon incorporation } \\
\text { of a complementary base to a newly synthesised DNA strand }\end{array}$ \\
\cline { 2 - 3 } & Bridge sequencing, Illumina technology & Synthesis by reversible termination; double-stranded adapters are attached to fragmented DNA \\
\cline { 2 - 3 } & lon Torrent sequencing & Synthesis with proton detection in an integrated circuit \\
\cline { 2 - 3 } & Sequencing by ligation (SOLiD) & Ligation of fluorescently labelled oligonucleotides on a microarray \\
\hline \multirow{4}{*}{$\begin{array}{l}\text { Third } \\
\text { generation } \\
\text { (NGS methods) }\end{array}$} & tSMS technology & Sequence determination without amplification \\
\cline { 2 - 3 } & FRET sequencing & Real-time DNA synthesis imitating DNA replication process \\
\cline { 2 - 3 } & SMRT sequencing & Synthesis and detection of single complementary nucleotides \\
\cline { 2 - 3 } & Nanopore sequencing & $\begin{array}{l}\text { Controlled cutting of nucleotides off a DNA strand that pass through nanopores in which } \\
\text { the intensity of electric current is measured }\end{array}$ \\
\hline $\begin{array}{l}\text { FRET - Förster resonance energy transfer; NGS - next-generation sequencing; PPi - pyrophosphate; SMRT - single-molecule real-time; tSMS - true single-molecule } \\
\text { sequencing. }\end{array}$ & \multicolumn{2}{|l}{} \\
\hline
\end{tabular}

Tab. 2. Sequencing techniques ${ }^{(7,8)}$

modification during individual development. The primary factor affecting the composition of the intestinal microbiota is mode of birth. Studies on stool samples of children born by caesarean section demonstrated a lower amount of Bifidobacterium and Bacteroides and a lower diversity of species compared to children born by natural delivery, both directly after birth ${ }^{(9)}$ and at 2 years of age $^{(10)}$. Despite a "Nature Medicine" report of 2017 indicating a lack of such differences in infants at week 6 of life ${ }^{(11)}$, natural delivery is widely considered to have a positive impact on the composition of the gastrointestinal microbiota.

Another important factor modelling intestinal biodiversity is the method of infant feeding. Natural feeding increases the numbers of Bifidobacterium and Lactobacillus (L. gasseri, L. salivarius, L. reuteri, L. fermentum), while formula feeding promotes the growth of Bacteroidetes, Clostridium, Streptococcus, Enterobacteriaceae and Veillonella ${ }^{(12-14)}$. Subsequent stages of child development, which involve complementary feeding, also have an effect on the microbiome composition, which stabilises at a level similar to that of adults only at 2-3 years of age $\mathrm{e}^{(15)}$.

In addition, in the course of ontogeny, various environmental factors affect the composition of the intestinal microbiome such as a change in place of residence, diet, lifestyle or level of activity, and antibiotic intake, which can significantly change the proportions of different bacterial species, causing dysbiosis. It is believed that diversity is the most important factor for the proper function of the microbiome. A favourable composition of microorganisms is that in which Bacteroides dominate over Prevotella. Such a microbiome is found in inhabitants of developing countries ${ }^{(16,17)}$. The diet is considered to be the primary reason for this. It was demonstrated that a diet rich in fruit and vegetables, among factors, results is an increased diversity of microorganisms in stool ${ }^{(18)}$. Research also shows that in individuals who eat lowfat or low-carbohydrate meals, apart from weight loss, a change in the intestinal bacterial profile is observed ${ }^{(19)}$. However, individuals who eat a Western-style diet rich in saturated fats and simple sugars are found to have a lower microbial diversity, particularly within the Firmicutes group, which leads to expansion of Proteobacteria.

\section{IMPACT OF INTESTINAL MICROBIOME ON HEALTH}

Shaping the intestinal microbiome at an early stage of life is the subject of intensive research; it involves supplying the child's gastrointestinal tract with "good" bacteria, prebiotics (non-digestible food ingredients which selectively stimulate the development and/or activity of one or a limited number of bacterial strains in the large intestine that have a positive effect on human health ${ }^{(20)}$ ), which include breast milk oligosaccharides, and immune components such as IgA immunoglobulins or lactoferrins.

There is a significant interest in postbiotics, i.e. all products of fermentation, including microbial cells, and their components and metabolites that have a positive effect on human health ${ }^{(21)}$. Few studies have been conducted on postbiotics to date, but they do seem to be a good alternative to probiotics due to their healthpromoting properties despite non-viability of the microbes involved ${ }^{(22)}$.

The microbiota plays a huge role in gastrointestinal processes. Through their enzymes and metabolites, which are referred to as intestinal metabolome, microorganisms affect the development of the intestinal mucosa, activation of digestive enzymes, peristalsis and nutrient absorption. In addition, they regulate the metabolism of bile acids, bilirubin, cholesterol, fatty acids and carcinogenic enzymes, and the production of vitamins ( $\mathrm{K}, \mathrm{B}_{12}$, folic acid). Microorganisms also contribute to shaping the immune and nervous systems as part of the gut-brain axis ${ }^{(23)}$.

Patients with intestinal microbiota imbalance may complain of intolerance to various dietary ingredients leading to such symptoms as excessive gas production, 
bloating and abdominal pain/discomfort. The results of research on the correlation between microbiome composition and functional gastrointestinal disorders are inconsistent. This may be due to differences in microbiome assessment methodology (in terms of type of sample: stool/mucosal bioptates/saliva/gastric contents and the gastrointestinal segment from which the material was collected) and selection of study groups (cultural, socioeconomic, ethnic and environmental differences: diet, therapy and exposure to other factors ${ }^{(1)}$. However, the vast majority of current studies indicate that there are decreased numbers and diversity of bacterial species in irritable bowel syndrome (IBS) ${ }^{(24,25)}$. In addition, in severe IBS, predominance of species from the genera Prevotella and Clostridium was demonstrated (a difference in a group of patients whose samples were studied using 16sRNA sequencing, with no differences revealed on traditional culture testing ${ }^{(26)}$.

Confirmation of a relationship between functional gastrointestinal disorders and dysbiosis allows one to conclude that a modification of the microbiota can result in a reduction of symptoms. In an experimental model of germ-free mice, a possibility was demonstrated of inducing visceral hypersensitivity through faecal transplant from animals colonised with pathological flora ${ }^{(27)}$. In a randomised, placebo-controlled study it was found that IBS symptoms can be alleviated using rifaximin ${ }^{(28)}$. In addition, in patients diagnosed with IBS a relationship was observed between microbiome modification through the use of probiotics ${ }^{(29)}$, faecal transplant or diet change ${ }^{(30)}$ and clinical improvement.

The role of intestinal microbiome composition in functional gastrointestinal disorders is the subject of intensive research, which makes it possible to apply specific therapeutic interventions and help patients.

\section{Conflict of interest}

The authors do not report any financial or personal affiliations to persons or organisations that could adversely affect the content of or claim to have rights to this publication.

\section{References}

1. Quigley EM, Barbara G, Feinle-Bisset $C$ et al.: The intestinal microenvironment and functional gastrointestinal disorders. In: Drossman DA, Chang L, Chey WD et al. (eds.): Rome IV Functional Gastrointestinal Disorders: Disorders of Gut-Brain Interaction. Vol. I, The Rome Foundation, Raleigh, NC 2016: 179-247.

2. Sender R, Fuchs S, Milo R: Revised estimates for the number of human and bacteria cells in the body. PLoS Biol 2016; 14: e1002533.

3. Gregorczyk-Maślanka K, Kurzawa R: Mikrobiota organizmu ludzkiego i jej wpływ na homeostazę immunologiczną - część I. Alerg Astma Immun 2016; 21: 146-150.

4. Sanger F, Nicklen S, Coulson AR: DNA sequencing with chain-terminating inhibitors. Proc Natl Acad Sci U S A 1977; 74: 5463-5467.

5. Fleischmann RD, Adams MD, White $\mathrm{O}$ et al.: Whole-genome random sequencing and assembly of Haemophilus influenzae Rd. Science 1995; 269: 496-512.

6. Venter JC, Adams MD, Myers EW et al.: The sequence of the human genome. Science 2001; 291: 1304-1351.

7. Orłowska M, Sobczyk M: Metody sekwencjonowania nowej generacji oraz ich wykorzystanie w genetyce, hodowli i biotechnologii roślin. Aparatura Badawcza i Dydaktyczna 2017; 22: 54-61.

8. Kotowska M, Zakrzewska-Czerwińska J: Kurs szybkiego czytania DNA - nowoczesne techniki sekwencjonowania. Biotechnologia 2010; 4: 24-38.

9. Biasucci G, Benenati B, Morelli L et al.: Cesarean delivery may affect the early biodiversity of intestinal bacteria. J Nutr 2008; 138: 1796S-1800S.

10. Jakobsson HE, Abrahamsson TR, Jenmalm MC et al.: Decreased gut microbiota diversity, delayed Bacteroidetes colonisation and reduced Th1 responses in infants delivered by caesarean section. Gut 2014; 63: 559-566.

11. Chu DM, Ma J, Prince AL et al.: Maturation of the infant microbiome community structure and function across multiple body sites and in relation to mode of delivery. Nat Med 2017; 23: 314-326.

12. Adlerberth I, Wold AE: Establishment of the gut microbiota in Western infants. Acta Paediatr 2009; 98: 229-238.

13. Fallani M, Young D, Scott J et al.; other members of the INFABIO Team: Intestinal microbiota of 6-week-old infants across Europe: geographic influence beyond delivery mode, breast-feeding, and antibiotics. J Pediatr Gastroenterol Nutr 2010; 51: 77-84.

14. Bezirtzoglou E, Tsiotsias A, Welling GW: Microbiota profile in feces of breast- and formula-fed newborns by using fluorescence in situ hybridization (FISH). Anaerobe 2011; 17: 478-482.

15. Szajewska H: Probiotyki i prebiotyki. In: Szajewska H, Horvath A (eds.): Żywienie i leczenie żywieniowe dzieci i młodzieży. Medycyna Praktyczna, Kraków 2017: 82-86.

16. El Aidy S, Hooiveld G, Tremaroli V et al.: The gut microbiota and mucosal homeostasis: colonized at birth or at adulthood, does it matter? Gut Microbes 2013; 4: 118-124.

17. De Filippo C, Cavalieri D, Di Paola $M$ et al.: Impact of diet in shaping gut microbiota revealed by a comparative study in children from Europe and rural Africa. Proc Natl Acad Sci U S A 2010; 107: 14691-14696.

18. Yatsuneko T, Rey FE, Manary MJ et al.: Human gut microbiome viewed across age and geography. Nature 2012; 486: 222-227.

19. Albenberg LG, Wu GD: Diet and the intestinal microbiome: associations, functions, and implications for health and disease. Gastroenterology 2014; 146: 1564-1572.

20. Ursell LK, Metcalf JL, Parfrey LW et al.: Defining the human microbiome. Nutr Rev 2012; 70 Suppl 1: S38-S44.

21. Collado MC, Vinderola G, Salminen S: Postbiotics: facts and open questions. A position paper on the need for a consensus definition. Benef Microbes 2019; 10: 711-719.

22. Malagón-Rojas JN, Mantziari A, Salminen S et al.: Postbiotics for preventing and treating common infectious diseases in children: a systematic review. Nutrients 2020; 12: 389. 
23. Cukrowska B: Znaczenie programowania mikrobiotycznego w rozwoju przewlekłych chorób infekcyjnych. Stand Med Pediatr 2016; 13: 1019-1028.

24. Giamarellos-Bourboulis E, Tang J, Pyleris E et al.: Molecular assessment of differences in the duodenal microbiome in subjects with irritable bowel syndrome. Scand J Gastroenterol 2015; 50: 1076-1087.

25. Maharshak N, Ringel Y, Katibian D et al.: Fecal and mucosa-associated intestinal microbiota in patients with diarrhea-predominant irritable bowel syndrome. Dig Dis Sci 2018; 63: 1890-1899.

26. Tap J, Derrien M, Törnblom H et al.: Identification of an intestinal microbiota signature associated with severity of irritable bowel syndrome. Gastroenterology 2017; 152: 111-123.e8.

27. Crouzet L, Gaultier E, Del'Homme C et al.: The hypersensitivity to colonic distension of IBS patients can be transferred to rats through their fecal microbiota. Neurogastroenterol Motil 2013; 25: e272-e282.

28. Pimentel M, Lembo A, Chey WD et al.; TARGET Study Group: Rifaximin therapy for patients with irritable bowel syndrome without constipation. N Engl J Med 2011; 364: 22-32.

29. Ford AC, Quigley EMM, Lacy BE et al.: Efficacy of prebiotics, probiotics, and synbiotics in irritable bowel syndrome and chronic idiopathic constipation: systematic review and metaanalysis. Am J Gastroenterol 2014; 109: 1547-1561.

30. Halmos EP, Power VA, Shepherd SJ et al.: A diet low in FODMAPs reduces symptoms of irritable bowel syndrome. Gastroenterology 2014; 146: 67-75.e5. 